JURNAL ILMIAH KEBIDANAN IMELDA

Vol.6, No.1, Maret 2020, pp. 17-20

ISSN: 2597-7180 (Online), 2442-8116 (Print)

\title{
PENGARUH USIA IBU TERHADAP KEJADIAN HIPERTENSI PADA WANITA PASANGAN USIA SUBUR DI PUSKESMAS BANGUN PURBA KABUPATEN DELI SERDANG TAHUN 2017
}

\author{
Rahmawani Fauza, Debora Lestari Simamora \\ Universitas Imelda Medan, Indonesia
}

\section{Article Info}

\section{Keywords:}

The Incidence of Hypertension Couples Of Childbearing Age Age

\begin{abstract}
Hypertension is a global problem. Data from WHO shows that the mortality rate caused by hypertension complications in 2013 reached 9.4 deaths worldwide. Further analysis conducted by RISKESDAS 2013 (Basic Health Research 2013) illustrates that the percentage of hypertension in women of reproductive age is $23.6 \%$. Women with chronic hypertension can cause complications during pregnancy compared to those without hypertension. The purpose of this study was to identify and analyze the factors that influence hypertension in women of reproductive age groups 15-49 years at the Bangun Purba Health Center, Deli Serdang Regency, in 2017.This research is a case control study that is unmatched. This research was conducted at the Bangun Purba Health Center, Deli Serdang Regency. The population was all women of childbearing age couples who were hypertensive or not who came for treatment at Puskesmas Bangun Purba from January 2016-March 2017, namely 541 women. The sample consisted of 49 respondents each in a case and control group. Data analysis consisted of univariate analysis, bivariate analysis with chi square. The results showed that the age variable affected hypertension in female partners of reproductive age 15-49 years. OR value $=3.6$ $(95 \% \mathrm{CI}=1,448-9,054)$ This means that respondents aged $>35$ years at risk are 3.6 times more likely to experience compared to respondents aged $\leq 35$ years. Based on an analysis of the effect of obesity on hypertension, a value of $<0.05$. In conclusion, the variable salt consumption, obesity and age affect the incidence of hypertension and the most influential variable is the salt consumption variable. Dietary arrangements to consume salt no more than 5 grams a day and maintain ideal body weight for women of reproductive age groups 15-49 years who are hypertensive or not.
\end{abstract}

This is an open access article under the CC BY-SAlicense.

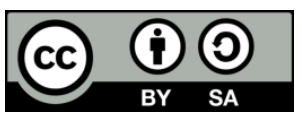

\section{Corresponding Author:}

Rahmawani Fauza,

Program Studi D-III Kebidanan,

Universitas Imelda Medan,

Jl. Bilal No. 52 Kelurahan Pulo Brayan Darat I Kecamatan Medan Timur, Medan - Sumatera Utara.

Email: rahmawani.29@gmail.com 


\section{INTRODUCTION}

Hipertensi merupakan masalah global dunia. Data WHO tahun 2013 kematian akibat komplikasi hipertensi mencapai 9,4 juta kematian di seluruh dunia. Pada tahun 2008 diseluruh dunia sekitar 40 persen orang dewasa berusia 25 tahun keatas telah didiagnosis menderita hipertensi. Data WHO 2010 juga menunjukkan diseluruh dunia, sekitar 972 juta orang atau 26,4 persen penduduk dunia mengidap hipertensi dengan perbandingan 26,6 persen pria dan 26,1 persen wanita. Angka ini diperkirakan akan terus meningkat menjadi 29,2 persen di tahun 2025. Dari 972 juta pengidap hipertensi 333 juta (34,3 persen) berada dinegara maju dan 639 juta (65,7 persen) sisanya berada di negara berkembang termasuk Indonesia (Masriadi, 2016). Hipertensi merupakan faktor risiko terpenting morbiditas dan mortalitas diseluruh dunia, baik pada laki-laki maupun perempuan. Antara tahun 2000 dan 2025 prevalensi hipertensi diprediksikan meningkat 9 persen pada laki-laki dan 13 persen pada perempuan. Hal ini disebabkan usia harapan hidup perempuanyang lebih panjang dibandingkan laki-laki, sehingga peningkatan prevalensi hipertensi pada perempuan meningkat melebihi laki-laki (Rilantono, 2013).

Sementara itu di Amerika Serikat terdapat 7,7 persen wanita usia subur yang mengalami hipertensi (Bateman, 2012). Hasil Survei Penduduk antar sensus (Supas) didapatkan jumlah penduduk perempuan usia 15-49 tahun menurut kelompok umur lima tahunan di Indonesia yaitu sebanyak 38.631.937. Analisis lanjut data RISKESDAS 2007 menunjukkan persentase hipertensi pada wanita yang tidak hamil (wanita yang termasuk usia subur) sebesar 23,6 persen. Di Sumatera Utara sendiri persentase hipertensi pada wanita tidak hamil sebesar 16,7 persen. Wanita dengan hipertensi kronis yakni kondisi hipertensi yang telah muncul sebelum kehamilan dapat memicu komplikasi saat kehamilan daripada mereka yang tidak memiliki hipertensi. Saat hamil, tekanan darah seseorang ibu dapat meninggi atau biasa disebut dengan hipertensi gestasional. Hal ini tentu berbahaya bagi ibu yang memang memiliki riwayat hipertensi sebelum hamil.

Menurut poenelitian tentang hipertensi menyatakan bahwa ada hubungan tingkat pengetahuan responden tentang hipertensi dengan tindakan mengontrol tekanan darah dengan hasil $\mathrm{p}=0,001(\mathrm{p}<0,05)$ (Damanik, 2016).

Berdasarkan survei pendahuluan yang dilakukan di Puskesmas Bangun Purba, penyakit hipertensi terus berada pada urutan kedua dari sepuluh penyakit terbesar pada tahun 2015 dan tahun 2016. Akan tetapi pada tahun 2016 terjadi kenaikan jumlah penderita hipertensi pada WUS dari 19 persen menjadi 21 persen. Dari hasil wawancara langsung dengan 6 orangwanita usia subur penderita hipertensi yang merupakan PUS di Puskesmas Bangun Purba ditemukan lebih dari separuhnya yaitu 4 orang (66 persen) menderita hipertensi tanpa memiliki riwayat keturunan hipertensi, usia dibawah 35 tahun, tidak obesitas dan tidak menggunakan alat kontrasepsi hormonal.

\section{RESEARCH METHOD}

Jenis penelitian yang digunakanadalah studi analitik observasional dengan disain studi Case Control. Sampel penelitian sebanyak 49 kasus dan 49 kontrol. Pengumpulan data dengan kuesioner. Analisis data dilakukan secara univariat, bivariat dengan menggunakan uji chi-square, multivariat dengan menggunakan uji regresi logistik.Penelitian ini dilakukan pada Januari 2016-Maret 2017. Tempat penelitian dilaksanakan di di Puskesmas Bangun Purba.

\section{RESULTS AND ANALYSIS}

Analisis Univariat

a. Karakteristik Responden

Karakteristik responden pada penelitian ini merupakan variabel bebas terdiri dari: pendidikan, pekerjaan, agama dan suku.

Tabel 1. Karakteristik Responden Berdasarkan Pendidikan, Pekerjaan, Agama, Suku

\begin{tabular}{|c|c|c|c|c|}
\hline \multirow{3}{*}{$\begin{array}{c}\text { Karekteristik } \\
\text { Responden }\end{array}$} & \multicolumn{4}{|c|}{ KejadianHipertensi } \\
\hline & \multicolumn{2}{|c|}{ Hipertensi } & \multicolumn{2}{|c|}{ TidakHipertensi } \\
\hline & $\mathbf{N}$ & $\%$ & $\mathbf{N}$ & $\%$ \\
\hline \multicolumn{5}{|l|}{ Pendidikan } \\
\hline $\mathrm{SD}$ & 11 & 22,4 & 8 & 16,3 \\
\hline SMP & 17 & 34,7 & 17 & 34,7 \\
\hline SMA & 12 & 24,5 & 11 & 22,7 \\
\hline D3 & 4 & 8,2 & 5 & 10,2 \\
\hline $\mathrm{S} 1$ & 5 & 10,2 & 8 & 16,3 \\
\hline \multicolumn{5}{|l|}{ Pekerjaan } \\
\hline PNS/TNI/POLRI & 12 & 24,5 & 10 & 20,4 \\
\hline Pegawai Swasta & 3 & 6,1 & 6 & 12,2 \\
\hline Wiraswasta & 6 & 12,2 & 2 & 4,1 \\
\hline
\end{tabular}

Jurnal Ilmiah Kebidanan Imelda, Vol. 6, No. 1, Maret 2020: 17-20 


\begin{tabular}{lcccc}
\hline Petani & 10 & 20,4 & 9 & 18,4 \\
Tidak bekerja & 18 & 36,7 & 22 & 44,9 \\
\hline Agama & & & & \\
Islam & 28 & 57,1 & 27 & 55,1 \\
Kristen & 21 & 42,9 & 22 & 44,9 \\
\hline Suku & & & & \\
Jawa & 12 & 40,0 & 18 & 60,0 \\
Batak & 37 & 54,4 & 31 & 45,6 \\
\hline
\end{tabular}

Berdasarkan tabel di atas dapat di ketahui bahwa sebagian besar responden berusia $>35$ tahun pada kelompok kasus 40 orang $(81,6 \%)$ dan responden kontrol 27 orang $(55,1 \%)$. Sebagian besar responden mempunya tingkat pendidikan SMPpada kelompok kasus 17 orang $(34,7 \%)$ dan kelompok kontrol 17 orang $(34,7 \%)$. Responden sebagian besar mempunyai Pekerjaan pada kelompok kasus IRT/tidak bekerja 18 $(36,7 \%)$ dan kelompok kontrol 22 (44,9\%). Sebagian besar responden beragama Islam pada kelompok kasus 28 orang $(57,1 \%)$ dan kelompok kontrol $27(55,1 \%)$. Sebagian besar responden dengan suku batak pada kelompok kasus 37 orang $(54,4 \%)$ dan kelompok kontrol 31 orang $(45,6 \%)$.

\section{b. Faktor Risiko}

Faktor risiko pada penelitian ini juga merupakan variabel bebas, terdiri dari riwayat keturunan, asupan garam, aktifitas fisik dan obesitas.

Tabel 2. Faktor Risiko Berdasarkan Umur, Obesitas, Konsumsi Garam, Riwayat Keturunan dan kontrasepsi Hormonal

\begin{tabular}{lcccc}
\hline \multirow{2}{*}{$\begin{array}{c}\text { Karekteristik } \\
\text { Responden }\end{array}$} & \multicolumn{4}{c}{ Kejadian Hipertensi } \\
\cline { 2 - 5 } & \multicolumn{2}{c}{ Hipertensi } & \multicolumn{2}{c}{ Tidak Hipertensi } \\
\cline { 2 - 5 } & $\mathbf{N}$ & \% & N & \% \\
\hline Umur & 9 & 18,4 & 22 & 44,9 \\
$<35$ tahun & 40 & 81,6 & 27 & 55,1 \\
\hline 35 tahun & &
\end{tabular}

Berdasarkan Berdasarkan tabel diatas dapat diketahui bahwa dari 98 responden, responden yang menderita hipertensi dan berumur > 35 tahun sebanyak 40 orang $(81,6 \%)$ sedangkan orang yang tidak menderita hipertensi tetapi berumur $>35$ tahun sebanyak 27 orang $(55,1 \%)$.

\section{Analisis Bivariat}

Untuk mengetahui ada tidaknya pengaruh faktor risiko terhadap kejadian hipertensi, maka dilakukan uji statistik dengan menggunakan uji chi square. Berdasarkan hasil uji statistik, untuk mencari adanya pengaruh umur terhadap hipertensi, diperoleh nilai $p<0,05$. Hal ini menunjukkan bahwa ada pengaruh umur terhadap kejadian hipertensi.

Tabel 3. Hasil Analisis Bivariat Faktor Risiko Berdasarkan, Umur, Obesitas, Konsumsi Garam, Keturunan dan Kontrasepsi Hormonal

\begin{tabular}{lccccc}
\hline \multicolumn{1}{c}{ Faktor Risiko } & Hipertensi (\%) & Tidak Hipertensi (\%) & $\boldsymbol{p}$ & OR & 95\% CI \\
\hline Umur & & & & & \\
\hline$>35$ tahun & $40(81,6)$ & $27(55,1)$ & $0,009^{*}$ & 3,621 & $1,448-9,054$ \\
$\leq 35$ tahun & $9(18,4)$ & $22(44,9)$ & & & \\
\hline
\end{tabular}

Keterangan: *Bermakna secara statistik $(p<0,05)$

Dari hasil analisis diperoleh nilai $\mathrm{OR}=3,6(95 \% \mathrm{CI}=1,448$ - 9,054) Hal ini berarti bahwa responden yang berumur > 35 tahun beresiko 3,6 kali lebih besar mengalami dibandingkan dengan responden yang berumur $\leq 35$ tahun. Berdasarkan analisis pengaruh obesitas terhadap hipertensi, diperoleh nilai $p<0,05$. Hal ini menunjukkan bahwa ada pengaruh obesitas terhadap kejadian hipertensi.

\section{CONCLUSION}

Melakukan kegiatan penyuluhan kesehatan reproduksi yang tidak hanya diprioritaskan kepada ibu hamil, bayi dan lansia akan tetapi juga meliputi bahaya penyakit tidak menular seperti hipertensi sebagai faktor risiko gangguan kesehatan reproduksi kepada wanita pasangan usia subur.Menjaga polamakanseperti membatasi konsumsi garam. Rasa asin yang berasal dari makanan adalah karena kandungan garam $(\mathrm{NaCl})$ yang ada dalam makanan tersebut, Konsumsi natrium yang berlebihan akan mempengaruhi, kesehatan terutama meningkatkan tekanan darah.

\section{REFERENCES}


Arikunto, S. (2010). Prosedur Penelitian Suatu Pendekatan Praktik. Jakarta: Rineka Cipta.

Arum, D. N. S., \& Sujiyatini (2014). Panduan lengkap pelayanan KB terkini. Yogyakarta: Nuha Medika.

BKKBN, (2013). Laporan umpan balik pelayanan kontrasepsi. http://aplikasi.bkkbn.go.id/sr, diperoleh tanggal 22 Oktober 2016.

Budiyanto, (2012). Mencegah kekanaikan berat badan akibat KB hormnal. http://blogspot.co.id/2014/11/mencegah-kegemukan-yang-disebabkan-oleh-hormon.html, diperoleh tanggal 03 Juni 2017.

Cipto Surono, (2000). Pengertian Berat Badan. https://pengertianberatbadan.wordpress.com/ diperoleh tanggal 19 oktober 2016.

Ganong, (2003). Hubungan antara hormon dan berat badan http://ehormon.blogspot.co.id/2014/11/hubungan-antara-hormon-dan-berat-badan.html, diperoleh tanggal 03 Juni 2017.

Hartanto, (2003), pengertian Akseptor KB. http://wawanjokamblog.blogspot.co.id/2009/07/akseptor-kb.html, diperoleh tanggal 22 Oktober 2016.

Hastono. P. S. , Sabri. L., (2010) Statistik Kesehatan Jakarta : PT Raja Grafindo Persada.

Hutauruk, P. M. (2019). Faktor - Faktor Yang Mempengaruhi Rendahnya Pengetahuan Ibu Untuk Memilih Implant Sebagai Alat Kontrasepsi Di Kelurahan Terjun Kecamatan Medan Marelan Tahun 2018. Jurnal Ilmiah Kebidanan Imelda, 5(1), 606-611.

Manuaba. I. A. C. , ((2009). Memahami kesehatan reproduksi wanita.Edis 2 : Jakarta : ECG.

Notoatmodjo.S., (2010).Metodologi penelitian kesehatan Jakarta : Rineka Cipta

Nugroho.T. \& Utama. I. B. Dr., (2014). Masalah kesehatan reproduksi wanita. Yogyakarta : Nuha Medika.

Kepmenkes RI, (2013), Situasi keluarga berencana di Indonesia. http//buletin-kespro.pdf. diperoleh tanggal 23 Oktober 2013.

Sibagariang,E., Pusmaika R., \& Rismalinda, (2010). Kesehatan Reproduksi wanita : Jakarta Timur : CV. Trans Info Media.

Siregar, E. (2009) Hubungan Antara penggunaan alat kotrasepsi suntik 3 bulan dengan Pertambhan berat badan akseptor KB.Jurnal kebidanan haga,2(4) Juni, 4-5.

Soetjiningsih, (1995), Pengertian Berat Badan.https://pengertianberatbadan.wordpress.com/di diperoleh 19 Oktober 2016.

Suparyanto, dr. (2010), Pengertian berat badan http://dr-suparyanto.blogspot.co.id/2010/12/pengaruh-kbsuntik-terhadap-perubahan.html, diproleh tanggal 22 Oktober 2016.

Surono C., 2009, pengertian berat badan. https://pengertianberatbadan.wordpress.com/diakses tanggal 19 oktober 2016.

Udin S. Winataputra, (2004), Pengertian Variasi. http://ghufron-dimyati.blogspot.co.id, diperoleh tanggal 05 November 2016.

Yanti, (2014) Buku ajarkesehatan reproduksi untuk mahasiswi kebidanan Yogyakarta : Pustaka Rihama.

\section{BIOGRAPHIES OF AUTHORS}

\begin{tabular}{|l|l|} 
Rahmawani Fauza, Gelar D-III diperoleh dari Akademi Kebidanan Imelda Medan, \\
Jurusan Kebidanan pada tahun 2007. Gelar D-IV diperoleh dari Universitas Sumatera \\
Utara, Jurusan Bidan Pendidik pada tahun 2009. Magister Kesehatan Masyarakat \\
diperoleh dari Universitas Sumatera Utara, Jurusan Kesehatan Masyarakat pada tahun \\
2018. Saat ini aktif sebagai dosen tetap di Prodi S1 Kebidanan Universitas Imelda \\
Medan.
\end{tabular} \mid $\begin{aligned} & \text { Debora Lestari Simamora, Gelar D-III diperoleh dari Akademi Kebidanan Imelda } \\
& \text { Medan, Jurusan Kebidanan pada tahun 2009. Gelar Sarjana diperoleh dari Poltekes } \\
& \text { Kemenkes RI Medan, Jurusan Bidan Pendidik Tahun 2011. Magister Kesehatan } \\
& \text { diperoleh dari Universitas Sumatera Utara, Jurusan Kesehatan Reproduksi pada tahun } \\
& \text { 2017. Saat ini aktif sebagai dosen tetap di Prodi D-III Kebidanan Universitas Imelda } \\
& \text { Medan. }\end{aligned}$

